\title{
An Experimental Designs For The Impact Of Attributed Organization Crisis Responsibility On Halal Organization Image As Mediated By Crisis Response Strategy
}

\author{
Nor Ez-Zatul Hanani Binti Mohamed Rosli, Rosmiza Binti Haji Bidin, Siti Zobidah Binti Omar, \\ Mohd Nizam Bin Osman, Julia Wirza Binti Mohd Zawawi
}

\begin{abstract}
In Malaysia, food crises related with Halal issues is becoming an imperative issue among Halal consumer with organizations facing crisis that have been suspected to sell NonHalal food products. This type of crisis has the potential to damage the organization image. Therefore, the adoption of appropriate crisis response strategy is needed in order to manage this outcome. In crisis communication field, experimental designs start to be adopted by many of researchers thus shift away from using the case studies. This phenomena occur due to the experimental research provides more understanding on the relationship and consequences of the crisis stimuli. Therefore, this research develop an experimental designs that using $3 \times 3$ between subjects factorial design, utilizing survey questionnaires as the instrument in order to investigate the crisis response strategies that most successfully accommodate the level of organization crisis responsibility perceived by the halal food consumer that will impact the organization image. In this research crisis response strategy will mediated the relationship between the organization crisis responsibility and organization image.
\end{abstract}

Keywords: Halal Food Crisis; Crisis Responsibility; Crisis Response Strategy; Organization Image; Experimental Research

\section{INTRODUCTION}

Regardless of the size, reputation or industry of an organization, there is always a potential for the crisis to occur in which it can comes through various shapes and forms [1].

Therefore, according to Krishnamoorthy [2], when the crisis hits the organization, public will be attracted to put concern on the evolution of the crisis. This befall because of the publicity by the media, hence indirectly will impact the image and reputation, sales and profit of the organization.

Among various types of crisis, research done by Hosseinali-Mirza, De Marcellis-Warin, \& Warin [3] found that product harm crisis is the most cited among the organizational crisis types. Product harm crisis has become a topic that fascinate the media attention and each passing year, it starts to grow into more complex, bigger and

Revised Manuscript Received on April 19, 2019.

Nor Ez-Zatul Hanani Mohamed Rosli, Department of Communication , Universiti Putra Malaysia, Serdang, Selangor, Malaysia.

Rosmiza Bidin, Department of Communication, Universiti Putra Malaysia, Serdang, Selangor, Malaysia.

Siti Zobidah Omar, Department of Communication , Universiti Putra Malaysia, Serdang, Selangor, Malaysia.

Mohd Nizam Osman, Department of Communication , Universiti Putra

Julia Wirza Mohd Zawawi, Department of Communication Universiti Putra Malaysia, Serdang, Selangor, Malaysia. Malaysia, Serdang, Selangor, Malaysia.

expensive issues to be concerned by the organization [4]. Furthermore, an experience from the past has shown that, organization has no immune on product-harm crisis and among all, the highest impact of tampering toward the public is fall under food harm category [5].

Thus, for Muslims countries, product harm crisis conceptualization is very much depending on the religious perceptions by the consumer [6]. Hence, Malaysia, with the Malay Muslims as the highest population [7] and has become Halal Food Benchmark that been acknowledged by The United Nations [8] the most important aspect that concern by the most Malaysian when related with food harm is Halal Issues. Study done by past research found that, attitudes of consumer in Malaysia has a relationship that significant with their intention of the halal food products [9].

There have been a number of times Malaysian Muslims faced organization crisis that have been suspected of selling non-halal products [10]. As an example the case that happened on March 2005 which involves Ikea Retail Malaysia. This organization has been ordered by the religious authorities to discontinue selling sausages that has been suspicious to be non-halal and closed their operation for a week [11]. In addition, McDonald in June 2014 also has faced the same issue in which the consumer claime that they are selling burger that made from non-halal product which is "Quarter Pounder" [10]. Other than that, High 5 bread (Silver Bird Group Bhd) in Nilai, Negeri Sembilan also has been shut down for two weeks due the issues of using cooking oil without a halal certification and contain lard [12]. The crisis happened that involve halal issue become a crucial consideration among the Muslim consumer, since purchasing halal products is a religious obligation for them [13]. Therefore, it is essential for the organization to identify suitable crisis response strategy in order to deal with Halal food harm crisis, since according to the past study, countless organizations are often fail to implement the suggestions offered in the crisis strategy [14]. As an example in the crisis of Cadbury Porcine DNA, 2014, according to Jaques [15], the responses by the organization on this crisis have been seen as overly passive and shockingly, it also did not follow exactly with any strategy of image restoration that suggested by the past research on product harm crisis. Thus, the impact that has to be endured 
by the Cadbury are image and reputation damage and call for the boycott by the Muslim groups [16].

Even though Situational Crisis Communication Theory (SCCT) that introduced by Coombs \& Holladay [17] has proposed a guideline on matched crisis response strategies with crisis types and been widely used by the researchers for product harm crisis involved, the strategies suggested is still vaguely address the issues. Subsequently, study done by Coombs \& Holladay [18] start to realize that for the product recalls and product harm crisis types, corrective action response strategy solely that suggested by the past study is not enough to manage the outcome of the crisis, thus they suggested for more studies to be done in determining what are the crisis response strategies that can be implemented to combine with the requisite corrective action strategy. Therefore, we can conclude that, there is still loophole on this query.

Hence from the discussion above, this paper is motivate to propose an experimental design method to investigate the crisis response strategies preferred by the Halal consumer for Halal food crisis in order to manage the image of the organization. Specifically in this research, crisis response strategy will mediated the relationship between the organization crisis responsibility and the outcomes of the Halal food crisis

\section{LITERATURE REVIEW}

Crisis communication has become a rapid developing field of research nowadays. When the crisis occur in the organization, it can vanish stakeholder supports towards the organization thus will harm the organizational image and reputation by creating negative public posts about the organization [19]. Eventually, a crisis will strike an organization [20] and curbing a crisis has become crucial to the organization. However, according to Vassilikopoulou, Siomkos, Chatzipanagiotou, \& Pantouvakis [21], it involves a complex and difficult procedure.

Hence, when a crisis hits, organization has the option whether to repudiate any responsibility or to admit full responsibility of the crisis [22]. However, since crisis has been seen as a negative occurrence, it leads stakeholders to evaluate organization crisis responsibility [23]. Research done by Coombs [24]-[25]-[22] define organization crisis responsibility as the amount of responsibility attributed by the stakeholder towards the organization for a crisis to occur. It is also the degree of responsibility and blame that public attribute on the organization through their observation of causing the crisis situation to occur [26].

Therefore, Coombs [27] categorizes organization crisis responsibility into three level of attribution which are very little attribution, minimal attribution and strong attribution of crisis responsibility. Research done by Coombs [22] found that crisis types will influence the stakeholder's attribution of crisis responsibility amount on the organization. In addition, Coombs \& Holladay [17] found that the attributions of the crisis responsibility has the relationship with the crisis response strategy.

Thus, Coombs [23] explains that crisis response strategy is what organization utters and execute when the crisis occur. According to $\mathrm{Ki}$ and Brown [28], it consists an exact more positive organizational image and reputation but when

setting that the spoke person of the organization utilize when respond to the crisis situation. On the other hand, crisis response strategy also can be explained as the choices that organization have in order to give respond during a crisis [19] and Coombs [29] pointed out that it is mainly about managing meaning that consist of the effects it is projected to have based on perception of the stakeholders towards the crisis situation. Based on Botan and Hazleton [30], the organization needs to meet stakeholder expectation in managing the negative impact of organization image and reputation and prevent any negative behavioral intentions towards the organization [23]. This is because the reaction of the publics on the crisis response strategies use by the organization indicates their acceptance or rejections of the crisis [31].

Hence, SCCT that develop by Coombs has been acknowledged by many researches as the guideline to choose crisis response strategy [32]-[33]-[34]-[35]. SCCT involves the relationships, variables and assumptions that need to be considered in choosing the suitable crisis response strategies to protect an organization's image and reputation [18]. Research done by Coombs [23]-[29] confirmed that SCCT offers four types of crisis response strategy that consist of deny strategy, diminish strategy, rebuilt strategy and bolstering strategy.

Coombs [29] explains that Deny strategy attempt to extinguish any connection that exist among organization and crisis, in which it emphasizes on the action of no responsibility. Under this strategy, it consists of ithe first one is attacking accuser strategy which is organization confronts the people who assert there is something wrong with the organization and the organization warn to take legal action towards the people who claim a crisis occurred; second is denial strategy which is organization asserts that there is no crisis and the organization said that no crisis event occurred; and third is scapegoat strategy which is organization put blames on people from the outside of the organization for the crisis [23].

Next for the Diminish strategy, it allows an organization to endure some responsibility for the crisis but in this strategy, organization claims that it has not much control on the situation and the crisis is not as poor as people think it is [29] Under this strategy it consists of i) Excuse strategy which is organization lessens organizational responsibility by rejecting the intention to do damage and/or claiming that the organization has no control on the events that generated the crisis; and ii) Justification strategy which is organization reduces the perceived damage triggered by the crisis by saying that the harm and injuries from the crisis were very trivial.

For the Rebuilt strategy, Coombs [29] explains that this strategy designed to emphasize on the victim concern in order to engage in positive actions to counterbalance negatives effects from the crisis. Therefore, under this strategy it consists of i) Compensation strategy in which organization provide money or other gifts to victims; and ii) Apology strategy in which organization accept full

Published By: 
responsibility for the crisis and asks stakeholder for forgiveness [23].

Lastly is Bolstering strategy in which this strategy seeks to include positive materials to the crisis situation in order to help counterbalance negative information generated by the crisis [29]. This strategy consists of i) Ingratiation strategy in which organization gives a compliment to the stakeholders for their support; ii) Reminder strategy in which organization inform the stakeholders about the organization previous good works; and iii) Victimage strategy in which organization explain to the stakeholder that they are together with the public become the victim of the crisis [23].

Roeder [36] express the opinion that SCCT provides a very worthwhile guideline for the organization to identify which strategy should be implemented and which should be evaded by the organization during managing the crisis. In the same way, Coombs [22] has also emphasizing on the importance of SCCT crisis response strategies guideline in order to fully protect the organization image and reputation.

Therefore, organization needs to choose a crisis response strategy that is suitable for the amount of image damage that a crisis may impose. The higher the potential image and reputational damage, the more accommodate the strategy that need to be used to the people that involves in the crisis [18]. This is because when crisis occurs to the organization, it has the potential to harm the organization image and reputation since it will contribute to the negative thinking among the public about the organization. Hence, stakeholder makes a comparison between their existing knowledge of the organization with some standard in order to determine whether or not an organization fulfills their expectations on how should organization behaves during the crisis [23]. Complementary to this, research done by Coombs [29] demonstrated that image and reputation repair seeks to reduce the negative effects a crisis has on the organization's image and reputation and other related assets.

A. Crisis response strategy as the mediator between organization crisis responsibility and the outcomes of the Halal food crisis

Crisis responsibility has played as a function of detector in identifies the emerging of image and reputation damage in the organization [34]. Research done by Coombs [25] found that organization crisis responsibility that attribute by stakeholder during the crisis is directly related to the image and reputational threat. According to Coombs and Holladay [17] the increase of public attribution of crisis responsibility to the organization will contribute towards the greater risk of organization image and reputational damage.

Furthermore, the correlation results in Coombs [25] research also shows that the reputational threat of a crisis will increase when the attributions of crisis responsibility increase thus, this support the core component of SSCT that emphasize on the existing of relationship between crisis responsibility and organization image and reputation. In addition, Park and Reber [37] claim that, even though stakeholder has favorable relationship with the organization, they are still have potential to put blame on the organization for unsuccessfully handling the crisis. Hence, they will attribute responsibility to the organization because in their point of view, organization needs to take suitable actions to reduce the uncertainty of the situation and control problems that related to the crisis.

Even though, research done by Kim [38] argues that even stakeholder attributes high level of organization crisis responsibility; they would not necessarily perceive a negative image and reputation of the organization due to the finding that shows rebuilding strategy has successful protect the image and reputation of the organization but Farah and Newman [39] emphasize that in the crisis that intersect with religion, stakeholder especially the Muslim group believes that it is essential for them to take action of this crisis thus they express this via attributed the responsibility towards the choices that they have (organization) and this make them tend to build their intention to participate in a boycotting the organization [40].

Therefore, the use of appropriate crisis response strategies can assist to lessen the impact on image and reputation damage in order to alleviate the disturbing emotions that cause from the attributions of the organization crisis responsibility by the stakeholder [17]. Hence, Coombs and Holladay [18] suggest to the organization to choose a crisis response strategy that appropriate to the level of crisis responsibility attributed by the stakeholder.

This can be done after evaluating the level of crisis responsibility attribute by the stakeholders. Finding from Dean [41] demonstrates that in the absence of any strategy to combat a crisis by the organization, crisis responsibility that attributed by the consumer will lead it to the negative outcomes of the crisis.

Hence, specifically in the dealing with product harm crisis, Laufer and Coombs [42] found that, organization will assess the amount of consumers attribute the blame on the organization for the crisis and by analyzing these, the organization can select the response strategy that best suits the level of blame attributed to the organization in order to manage the image and reputation of the organization. Thus, crisis communication strategy is the symbolic resources organization employs in order to protecting or repairing the organizational image and reputation [43].

Based on research done by Coombs and Holladay [17], crisis response strategy that matched with recommendation by SCCT were related to have more positive organizational image and reputation in comparison with either the no response or a mismatched response which is strategy that has not recommended by the SCCT. In addition, Coombs [44] also supports that different responses (matched vs. mismatched) for the same crisis will impact differently on image and reputation of the organization and the results show that the organizational image and reputation was significantly more positive in the matched conditions than in the mismatched ones. On the contrary, Claeys, Cauberghe \& Vyncke [45] in their research found the different result regarding this in which they found that matching crisis types and crisis response strategy does not necessarily lead to more positive perception of the organization image and reputation than mismatches. However, apart from this, 
organization crisis response strategy has been proved to significantly affect stakeholder attitude towards the organization and thus influences their score on organization image and reputation [46].

Specifically for the product harm crisis, Coombs [44] emphasizes that crisis response strategy that shows more compassion is able to give more protection on the image of organization since finding from the experiment shows the significant improvement of organization image and reputation when more compassion crisis responses towards the consumer been used. . Research done by Laufer and Coombs [42] explain that an important issue that has been faced by the organization that involved in a product harm crisis is to select the most appropriate response strategy that can lessen the image and reputation damage. Hence, they proposed to the organization to use voluntary recall strategy. However, one additional point should be made about recalls and product harm crisis types, they will involve the corrective action crisis response strategies (recall) but it must be combined with the requisite corrective action crisis response strategies in order to manage the image and reputation of the organization [18].

Therefore, in this study corrective action crisis response strategies will be combined with SCCT crisis response strategy that consist of Diminish strategy, Rebuilt strategy and Bolstering strategy. However, Denial response strategy is not chosen in this study due to the research done by Arendt, LaFleche and Limperopulos [47] that analyzed 110 articles across 51 peer-reviewed journals from 1986 to 2016 that found it is to be the least successful strategy to restore the image and reputation of the organization even though it was common strategy used by the organization in handling the crisis.

\section{METHODOLOGY/MATERIALS}

The strategy of inquiry for this research is experimental method in which $3 \times 3$ between subjects factorial design utilizing survey questionnaires as the instrument will be used. According to SAS Institute Inc., [48], experiment is conducted in situations in which researchers can control the factors that are irrelevant to research objectives by manipulate the condition of the experiment. In addition, experiment also has been used to examine the cause and effect relationship between variables [49]. Research done by Thorson, Wicks, and Leshner [50] also emphasize on the important of the experiment method to the mass communication field especially for the theoretical development. This is because, according to them, experiment is the most meticulous way to establish causal relationships between independent and dependent variables as well as moderators and mediators that are critical relationships for building and evaluating theory. In crisis communication field, $\mathrm{Ki}$ and Brown [28] found that most of the researchers start to adopt experimental designs and moving away from using case studies due to experimental designs propose a stronger understanding on the effects of certain crisis stimuli. Therefore, In this research $3 \times 3$ factorial design with the between subjects factors of the organization crisis responsibility (very little, minimal, strong) and crisis response strategy (voluntary recall + Diminish/Reducing offensiveness crisis response strategy, voluntary recall + Rebuilt/Redress crisis response strategy, voluntary recall + Bolstering crisis response strategy) will be established.

\section{A. Design Materials and Stimulus}

The crisis situation chosen for this research is Halal food crisis of organization that venture in the bread industry. Halal bread crisis is selected because according to Ling [51] the bread industry in Malaysia is obtaining much popularity and start to boom very rapidly. Not only that, it also has become the most commercial substitute of rice among Malaysians and the bread industry has been sprightly in fulfilling consumer's demand for various types of its products in Malaysia [52]. Furthermore, bread has increasingly being consumed as part of breakfast since it can supply the body with the required amount of energy needed during the day [53]. Research done by Mohd Nasir et al., [54] proved that, bread has become the second common breakfast among children in Malaysia. In addition, bread can easily be bought from several places for example supermarket, grocery shop or stall along the road [52]. In relation to this, when the Halal crisis related with the bread product occur, it has a huge potential to widely affect Halal consumer.

Therefore, fictitious information of the organization background that venture in Halal bread industry in Malaysia will be created. The organization background will be presented as the large and successful organization whose business had grown substantially over past few years and an imagery organization name will be used in this research. According to Fuoli, van de Weijer, and Paradis [55], imagery organization name and fictitious background information can prevent the influence of previous knowledge and attitudes towards the organization on the participant's response in idiosyncratic ways and to control their individual biases. Claeys, Cauberghe and Vyncke [45] in their research also agree that by using a fictitious organization scenario, potential confounding effects of preexisting knowledge can be avoided.

Next, a news article about the organization face Halal bread crisis scenario will be created based on previous halal food crisis case. This technique has also been used by the past study such as Park and Reber [37] that created the university crisis case on the basis of the crisis that happened to another university. Therefore, the scenario of The High 5 bakery in Nilai, Negeri that was raided by the authorities, who alleged it was unhygienic, employed illegal workers, used non-Halal cooking oil and its halal certification was withdrawn [12] will be duplicated in this research.

Then, fictitious news articles that contain manipulation of different combination crisis response strategy and voluntary recall only response strategy used by the organization to manage the crisis will be created. The use of news article in this research is accordance to what have been implemented by the past study [55]-[34]-[28]-[32]. In addition research done by Coombs [25] found that, the news media, particularly newspapers are effective in creating an agenda

Published By:

Blue Eyes Intelligence Engineering

$\&$ Sciences Publication 
setting effect for organizational image and reputation in which what is reported about the crisis by the newspapers can have a thoughtful effect on the organization's image and reputation.

In this research, the news articles writing style, format and template will be copy exactly the same from an actual context of online newspaper articles. The article will be made to look as it is print from the newspaper website. Past study such as Dardis and Haigh [56] in their research that related with food crisis also used the same materials design to develop their experiment.

\section{B. Content validation}

For the experimental research, according to Bhattacherjee [57] the validity for this method is based on how well the treatment was manipulated. The manipulation of the treatment can be checked by using pretest and pilot test prior to the experimental research. Furthermore, manipulation check is also will make certain on the operationalization of the variables tested are what the research intended thus respondents perceptions to the conditions to which they are exposed to will often be investigated [49]

In this research, the manipulation of combination crisis response strategy will be tested using Kiambi and Shafer [34] technique of manipulation in which a pretest will be conducted with randomly 60 selected respondents and the stimuli articles and manipulation checks articles will be distributed to them. Every respondent then will answer a series of items to evaluate whether they realize or not the crisis response strategy used by the organization using 7point Likert scale ranging from 1 (strongly disagree to 7 strongly agree).

Furthermore, in order to ensure the correct and consistent writing style and content of all the articles provided in this research, a cross-check the stories will be done with the journalism who is expert in this area since it is important to provide a similar setting as possible to the actual crisis. This technique also has been adopted by Park and Reber [37] in which they tested the successful of crisis-response strategies manipulation in their study with nine graduate students majoring in mass communication and journalism.

\section{Sample/Participant}

A sample can be defined as one of many possible sub-sets of units that are selected from the population. Before any sample to be determined, it is important to clearly define the this, the population of this research is Halal bread consumer.

According to Ling [51], bread has been circulated within the whole country from the rural areas to the big cities and can be purchased at many places for example convenience stores, normal grocers, supermarkets, mini-markets and petrol station stores. Furthermore, in terms of the age factor, bread are consume by all segments of consumer in which Mohd Hasri and Azmi [52] in their research found that, bread organization such as Gardenia provides diversity of products to fulfil all needs of consumers. This has been agree by Ling [51] in which she mention that wide range of selections make bread to become a popular food and affordable for people from all ages and incomes. population of the research interest first [48]. In relation to

Subsequently, research done by Mohd Hasri and Azmi [52] also revealed that bread is popular among Malay, Chinese and Indians in Malaysia and become the whole food consumption of the day especially for their breakfast time. Ling [51] agreed that bread is also beginning to be consume as a lunch meal among the working people especially when the weather depresses them from taking a rice or noodle for lunch. Therefore, based on discussion on the population of bread consumer, the sample that best represent the population of Halal bread consumer in this research is working people at the organization.

The sampling method that will be used for the experiment in this research is random selection and random assignment method. According to Bhattacherjee [57] random selection is the process of choosing a sample randomly from a population or a sampling frame and random assignment in the other hand is an assigning process randomly as the subjects to experimental group or control group. Furthermore, Neuman [58] also explain that the random assignment is a way to divide a collection of participants into two or more groups that can increase the confidence level that the groups do not differ in a systematic way.

For the sample size determination, according to Bhattacherjee [57] each cell should have a minimum sample size of 20 (this estimate is derived from Cohen's power calculations based on medium effect sizes) in a factorial design experiment. This is accordance to the rule of thumb for the factorial design experiment sample size. Therefore, in this research, $3 \times 3$ between subjects factorial design requires a minimum total sample size of 180 respondents.

\section{Type of variables}

According to Creswell [59] the variables hasto be specified in an experiment in order to provide clear idea to the readers of what groups are receiving the experimental treatment and what outcomes are being measured. First and the foremost is the independent variable which is organization crisis responsibility. Independent variable in this research will be fix treatment factor in which categories of organization crisis responsibility will be perceived by the respondents through the fix article of Halal food crisis happen in the organization across all the conditions and the respondent's attribution of organization crisis responsibility will be grouped into Coombs [27]-[29], crisis responsibility categories which are very little attribution, Minimal attribution and strong attribution. Research done by Crijns, Cauberghe, Hudders, and Claeys [60] also has adopted the same fix treatment in their independent variable in which they assigned fix photo of spokesperson in order to identify the gender similarity factor then they group into similar and different.

The second variable is the mediator which is crisis response strategy. According to Pirlott and MacKinnon [61] mediator can be defined as the generative mechanism that will influence the independent variable and the dependent variable and in this way it accounts for the relation between the predictor and criterion. In this research the effectiveness of mediator which is crisis response strategy becomes a 
main interest in this research in which it will be manipulated in order to see how the Halal food consumer evaluates the effectiveness of each crisis response strategy provided by the organization in order to identify the best crisis response strategy preferred by the Halal food consumer. The manipulation of crisis response strategy has been widely used by many past scholars in order to evaluate the effectiveness of the crisis response strategy adopted [32]-[34]-[60]. Therefore, crisis response strategy that will be used in this research are i) voluntary recall + Diminish/Reducing offensiveness crisis response strategy; ii) voluntary recall + Rebuilt/Redress crisis response strategy; and iii) voluntary recall + Bolstering crisis response strategy.

The last variable is dependent variables which is organization's image. Based on research done by Coombs and Holladay [32], reputation (image) can be measured through the comparison between prior reputations (image) before the crisis happen and post reputation (image) after the crisis happened. Thus in this study, the organization's image will be influence by the independent variable, and the mediator.

\section{E. Design Procedures}

In this research, the experiment will be conducted in an organization during the organization board meeting in which before the organization start the meeting with all their employee. Employee will randomly be given the number of one (1), two (2) three (3) and four (4) once they enter the venue of the meeting and they will verbally instructed to sit according to the number received. Four different groups are actually will represent 4 different treatment groups in which include 1 control group and 3 experimental groups.

At the first stage, respondents will be given fictitious information of the successful organization background that venture in Halal bread industry in Malaysia in which an imagery organization name will be used in this research. After reading the background information, respondents will ask to complete the questionnaire on organization pre-image together with the demographic questions.

At the second stage, a news article about the organization face Halal food harm crisis will be given to the respondents. The article depicting The Halal harm crisis scenario will be assigned to all the conditions thus it is a fix factor in this experiment. After reading the article, respondents will ask to evaluate the attribution of the organization crisis responsibility (independent variables) on the crisis. In this research, respondents will be asked to categorized two items of organization responsibility into Coombs [23]-[29] crisis responsibility categories which are very little attribution, minimal attribution and strong attribution.

At the third stage, respondents will be given an article that contains the combination of crisis response strategy (mediator) used by the organization. For the control group, a response article that contains only voluntary recall response strategy used by the organization to manage the crisis will be given to the respondents. In the other hand, for the other 3 experimental groups, each group will be provided with the article that contains manipulation of different crisis response strategy i) voluntary recall + Diminish/Reducing offensiveness crisis response strategy; ii) voluntary recall +
Rebuilt/Redress crisis response strategy; and iii) voluntary recall + Bolstering crisis response strategy use by the organization to manage the crisis. After reading the article, respondents will ask to evaluate the effectiveness of the crisis response strategy use by the organization and the organization image (dependent variables) after the crisis happen.

\section{CONCLUSION}

Through the experiment that will be run, this research is expected to contribute in providing suitable crisis response strategies that can be used by the organization that venture in halal industry product specifically food product when combat the crisis that associated with halal issues which, in return will benefit the halal industry in Malaysia in order to protect the image and reputation of the industry and intention of boycotting the halal food products.

Furthermore, due to the fact that every organization has the potential to face any types of crisis, this research will provide crisis managers with knowledge for making informed decisions concerning ways to protect organizational image through the selection of appropriate crisis response strategies for Halal food crisis. Additionally, this research also will further enrich crisis manager understanding on the impact of crisis type and customer background (religion) towards the attribution of crisis responsibility on the organization perceived by the consumer that will influence the effectiveness of the crisis response strategies used by the organization to protect organization image and boycotting intention.

Equally important, this research will contribute to the field of crisis communication by offering support on the existing theories of SCCT that helps crisis managers understand his/her option in dealing with crisis to protect image of the organization and manage the intention of boycotting the organization. Nonetheless, this research will further emphasize on the improvement of SCCT by adding other components that can influence the relationship between attribution of crisis responsibility on the organization and the effectiveness of crisis response strategies use by the organization to protect the reputation of the organization and manage intention of boycotting the organization by the customer.

\section{REFERENCES}

1. A. Mohamad Ashari, D. A. M. Abang Ahmad, and M. C. Samani, "Crisis response strategy and crisis types' suitability: A preliminary study on $\mathrm{mH} 370$," SHS Web of Conference (i-COMEC'16)., 2017

2. M. Krishnamoorthy, (2013, June 22). When in a media crisis, stay calm. Available: http://mystarjob.com/articles/story

3. V. Hosseinali-Mirza, N. De Marcellis-Warin, and T. Warin, "Crisis communication strategies and reputation risk in the online social media environment," International Journal of Business and Social Science. vol. 6 (5), 2015, pp. 7-21. 
4. S. P. Costello, and K. A. Furfari, The product crisis: Staying ahead by planning ahead. Jones Day Publication, 2008.

5. U. Haas-Kotzegger, and B. B. Schlegelmilch, "Conceptualizing consumers' experiences of productharm crises," Journal of Consumer Marketing, vol. 30 (2), 2013, pp. 112-120.

6. V. P. Goby, and C. Nickerson, "The impact of culture on the construal of organizational crisis: perceptions of crisis in Dubai," Corporate Communication: An International Journal., vol. 20(3), 2015, pp.310-325.

7. Department of Statistic Malaysia (2015). Available: https://www.dosm.gov.my/v1/index.php

8. A. M. Bohari, C. W. Hin, and N. Fuad, "The Competitiveness of Halal Food Industry in Malaysia: A SWOT-ICT Analysis," Geografia Malaysian Journal of Society and Space [Online]., vol. 9(1), 2013, pp. 1-9.

9. A. Abd Rahman, E. Asrarhaghighi, and S. Ab Rahman, "Consumers and Halal cosmetic products: knowledge, religiosity, attitude and intention," Journal of Islamic Marketing., vol. 6(1), 2015, pp. 148-163.

10. The Malay Mail Online (2017, March 28). Halal or not: The times Malaysians jumped the gun and sparked a food war. Available: http://www.themalaymailonline.com/malaysia/article/

11. M. Tieman, "Halal certification procedure: Some unresolved issues," Journal of Islam and Civilizational., vol. 6(1), 2017, pp. 124-4.

12. S. Low. (2007, May 6). Dealing with crisis chaos. The https://www.thestar.com.my/data/archives/2013/07/06/08 /45/dealing-with-crisis-chaos/

13. M. Tieman, "Halal risk management: combining robustness and resilience," Journal of Islamic Marketing., vol. 8(3), 2015, pp. 461-475.

14. S. J. Holladay, "Crisis Communication Strategies in the Public Relations Research., vol. 21(2), 2009, pp. 208217.

15. T. Jaques, "Cadbury and pig DNA: when issue management intersects with religion," Corporate Communications: An International Journal., vol; 20(4), 2015, pp. 468-482.

16. BBC World News (2014, June 2). "Cadbury Chocolate pork free, Says Malaysian Islamic body. Available: http://www.bbc.com/news/business-27663857

17. W. T. Coombs, and S. J. Holladay, "Communication and Attributions in a crisis: An experimental Study in Crisis Communication," Journal of Public Relations Research., vol. 8(4), 1996, pp. 279-295.

18. W. T. Coombs, and S. J. Holladay, "Helping Crisis Managers Protect Reputational Assets," Management Communication Quarterly., vol.16 (2), 2002, pp.165-186.

19. W. T. Coombs, "Making sense sensibly in crisis communication: How publics' crisis appraisal influence their negative emotions, coping strategy preference, and crisis response acceptance," in Y. Jin (Eds.), Crisis communication Volume II. London: SAGE. , 2014, pp.335 .

20. W. T. Coombs, "Information and compassion in crisis responses: a test of their effects," Journal of Public Relations Research, vol. 11(2), 1999.

21. A. Vassilikopoulou, G. Siomkos, K. Chatzipanagiotou, and A. Pantouvakis, "Product-harm crisis management: time heals all wounds?" Journal of Retailing and Consumer Services., vol. 16(3), 2009, pp. 174-180.

22. W. T. Coombs, "The protective powers of crisis response strategies: Managing reputational assets during a crisis," Journal of Promotion Management., vol. 12(3/4), 2006, pp. 241-260. Star Online. Available: Media Coverage of Chemical Accidents," Journal of

23. W. T. Coombs, "Attribution Theory as a guide for postcrisis communication research," Public Relations Review., vol. 33(2), 2007a, pp. 135-139.

24. W.T. Coombs, "Impact of past crises on current crisis communications: Insights from Situational Crisis Communication Theory," Journal of Business Communication., vol. 41, 2004, pp. 265-289

25. K., Brown, and E.-J. Ki, "Developing a Valid and Reliable Measure of Organizational Crisis Responsibility," Journalism \& Mass Communication Quarterly., vol. 90(2), 2013, pp. 363-384.

26. W. T. Coombs, "Protecting Organization Reputations During a Crisis: The Development and Application of Situational Crisis Communication Theory," Corporate Reputation Review., vol. 10(3), 2007b, pp.163-176.

27. E.-J. Ki, and K. A. Brown, "The Effects of Crisis Response Strategies on Relationship Quality Outcomes,' International Journal of Business Communication., vol. 50(4), 2013, pp. 403-420

28. W. T. Coombs, "The value of communication during a crisis: Insights from strategic communication research," Business Horizons., vol. 58(2), 2015, pp.141-148.

29. C. H. Botan, and V. Hazleton, "Crisis management: A communicative approach," in W.T. Coombs (Eds.), Public relations theory II, Mahwah, New Jersy: Lawrence Erlbaum Associates, 2006, pp. 171-197.

30. W. T. Coombs, and S. J. Holladay, "How publics react to crisis communication efforts: Comparing crisis response reactions across sub-arenas," Journal of Communication Management., vol. 18(1), 2014, pp. 4057.

31. W.T. Coombs, and S. J. Holladay, "Comparing apology to equivalent crisis response strategies: Clarifying apology's role and value in crisis communication," Public Relations Review., vol. 34, 2008, pp. 252-257.

32. J. Choi, and W. Chung, "Analysis of the interactive relationship between apology and product involvement in crisis communication: An experimental study on the Toyota recall crisis," Journal of Business and Technical Communication., vol. 27 (1), 2013, pp. 3-31.

33. D. M. Kiambi, and A. Shafer, "Corporate Crisis Communication: Examining the Interplay of Reputation and Crisis Response Strategies," Mass Communication and Society., vol. 19(2), 2015, pp. 127-148.

34. S. Roh, "Examining the paracrisis online: The effects of message source, response strategies and social vigilantism on public responses," Public Relations Review., vol. 43(3), 2017, pp. 587-596.

35. M. Roeder, Examination of the Efficacy of Situational Response Strategies Utilized in Crises Instigated or Aggravated by Viral Videos that Threaten Harm to Reputation or Brand. (Master's Thesis). Gonzaga University: United States, 2015.

36. H. Park, and B. H. Reber, "The organization-public relationship and crisis communication: The effect of the organization-public relationship on publics' perceptions of crisis and attitudes toward the organization," International Journal of Strategic Communication., vol 5(4), 2011, pp. 240-260.

37. S. Kim, "The role of prior expectancies and relational satisfaction in crisis," Journalism and Mass Communication Quarterly., vol. 91(1), 2014, pp. 139158 .

38. M. F. Farah, and A. J. Newman, "Exploring consumer boycott intelligence using a socio-cognitive approach," Journal of Business Research., vol. 63(4), 2010, pp. 347355 . 
39. B. Paula, A. Cruz, and S. D. Ross, "The Buycott intention analyzed from sexual orientation and religion: The O Boticario ' s Brazilian case," Almanaque Multidisciplinar De Pesquisa., vol. 1, 2016, pp. 4-31.

40. D. H. Dean, "Consumer reaction to negative publicity: Effects of corporate reputation, response, and responsibility for a crisis event," Journal of Business Communication., vol. 41(2), 2004, pp. 192-211.

41. D. Laufer, and W. T. Coombs, "How should a company respond to a product harm crisis? The role of corporate reputation and consumer-based cues," Business Horizons., vol. 49(5), 2006, pp. 379-385.

42. W. T. Coombs, "An analytic framework for crisis situations: better responses from a better understanding of the situation," Journal of Public Relations Research., vol. 10(3), 1998, pp. 177-191.

43. W. T. Coombs, "Information and compassion in crisis responses: a test of their effects", Journal of Public Relations Research., vol. 11(2), 1999.

44. A. S. Claeys, V. Cauberghe, and P. Vyncke, "Restoring reputations in times of crisis: An experimental study of the Situational Crisis Communication Theory and the moderating effects of locus of control," Public Relations Review., vol. 36(3), 2010, pp. 256-262.

45. H. Park, "Exploring effective crisis response strategies," Public Relations Review., vol. 43(1), 2017, pp. 190-192.

46. C. Arendt, M. LaFleche, and M. A. Limperopulos, "A qualitative meta-analysis of apologia, image repair, and crisis communication: Implications for theory and practice," Public Relations Review, vol. 43(3), 2017, pp. 517-526.

47. SAS Institute Inc. Concepts of experimental design: Design Institute for Six Sigma. USA: A SAS White Paper, 2005.

48. L. A. Baxter, and E. Babbie, The basic of communication research. Wadsworth : Thomson, 2004.

49. E. Thorson, R. Wicks, and G. Leshner, "Experimental methodology in journalism and mass communication research," Journalism and Mass Communication Quarterly., vol. 89(1), 2012, pp. 112-124.

50. C. N. Ling, "An Overview of the Evolution of the Bread Industry in Malaysia," Agricultural Engineering in Malaysia 11th YEAFEO Conference., 2005, pp. 14-17

51. Mohd Hasri and Asyikin Azmi "Marketing environment, segmentation and targets in Penisular Malaysia: The case of Gardenia Bakeries Snd Bhd," International Journal of Humanities and Social Science Invention., vol. 5 (12), 2016, pp. 24-30.

52. M. O. Aljobair, "Assessment of the Bread Consumption Habits Among the People of Riyadh, Saudi Arabia," Pakistan Journal of Nutrition., vol. 16 (5), 2017, pp. 293 298.

53. Mohd Nasir et al., "Consumption of ready-to-eat cereals (RTEC) among Malaysian children and association with socio-demographics and nutrient intakes - findings from the MyBreakfast study," Food and Nutrition Research., vol. 6, 2017.

54. M. Fuoli, J. van de Weijer, and C. Paradis, "Denial outperforms apology in repairing organizational trust despite strong evidence of guilt," Public Relations Review., vol. 43(4), 2017, pp. 645-660.

55. F. Dardis, and M. M. Haigh, "Prescribing versus describing: testing image restoration strategies in a crisis situation," Corporate Communications: An International Journal., vol. 14 (1), 2009, pp. 101-118.

56. A. Bhattacherjee, Social Science Research: Principles, Methods, and Practices. North Charleston SC, United States: Create space Independent Publishing Platform, 2012.
57. W. L Neuman, Social Research Methods: Qualitative and Quantitative Approaches. Harlow, United Kingdom: Pearson Education Limited, 2011.

58. J. W. Creswell, Research design: Qualitative, quantitative, and mixed method. Research design Qualitative quantitative and mixed methods approaches. Sage. Los Angeles, 2014.

59. H. Crijns, V. Cauberghe, L. Hudders, and A. S. Claeys, "How to deal with online consumer comments during a crisis? The impact of personalized organizational responses on organizational reputation," Computers in Human Behavior., vol. 75, 2017, pp. 619-631.

60. A. G. Pirlott, and D. P. MacKinnon, "Design approaches to experimental mediation," Journal of Experimental Social Psychology., vol. 66, 2016, pp. 29-38.

\section{AUTHORS PROFILE}

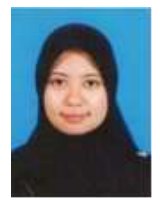

Nor Ez-zatul Hanani Mohamed Rosli is at present lecturer at Department of Public Relations, Faculty of Arts and Social Science, Universiti Tunku Abdul Rahman, Kampar, Perak. She is also a Phd Student at Universiti Putra Malaysia, Malaysia. She holds Bachelor Degree (Communication) and Master Degree (Communication) at Universiti Sains Malaysia, Malaysia. Her research interest is on crisis communication, crisis management, organization image and reputation.

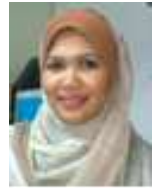

Rosmiza Bidin is an affiliated researcher at the Hala Product Research Institute, Universiti Putra Malaysia, Malaysia. She is also a Senior Lecturer at the Department of Communication, Faculty of Modern Languages and Communication, Universiti Putra Malaysia, and a Fellow at the Corporate Communication and Strategic office, Universiti Putra Malaysia. She earned her first degree in Psychology from International Islamic University Malaysia, her Master of Science Degree in Organisational Communication from Universiti Putra Malaysia, and her $\mathrm{Ph} . \mathrm{D}$ in Branding in Universiti Sains Malaysia . Her research interest is on corporate identity, image and reputation, as well as on branding communication and technology. She has been involved conducting several researches and presentations in her areas of expertise at the local as well as the international level.

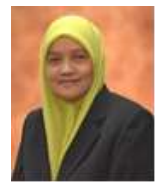

Siti Zobidah Omar is a Deputy Director, Institute for Social Science Studies, Universiti Putra Malaysia, Malaysia. She is also an Associate Professor at the Department of Communication, Faculty of Modern Languages and Communication, Universiti Putra Malaysia. She earned her first degree in Mass Communication (Journalism) from University of Mara Technology (UiTM) Malaysia, her Master of Arts Degree in Communication Technology and Policy from Macquarie University, Sydney, Australia and her Ph.D in Communication Technology and Culture from The University of Birmingham, United Kingdom. Her research interest is on use of new media, communication technology and culture particularly on the use of ICT and culture. She has been involved conducting several researches in her area at local and global level.

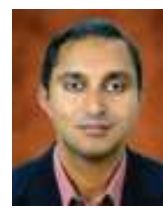

Mohd Nizam Osman is at present a senior lecturer at the Department of Communication, Faculty of Modern Languages and Communication, Universiti Putra Malaysia. His PhD dissertation was focused on media studies in developed and developing countries and his $\mathrm{PhD}$ degree was obtained from the University of Sussex, United Kingdom in 2004. His Masters degree in Mass Communication and Bachelor degree in Organizational Communication were obtained from Western Michigan University, USA in 1996 and 1994,

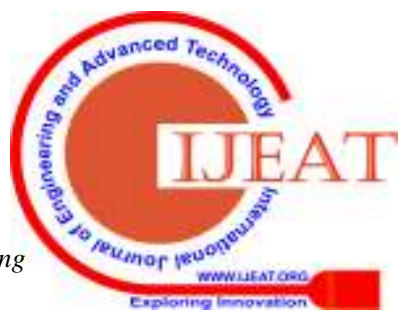


respectively. His research interests and area of specialization include broadcasting and telecommunication, radio and television production, government policies in developed and developing countries and communication technology policies.

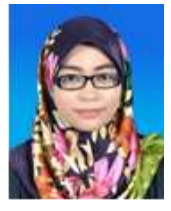

Julia Wirza Mohd Zawawi is a senior lecturer at the Department of Communication, Faculty of Modern Languages and Communication, Universiti Putra Malaysia. She earned her first degree in Public Management from Universiti Utara Malaysia (UUM), her master degree of Social Science (Communication Management) and Ph.D (Communication) from Universiti Kebangsaan Malaysia (UKM). Her research interest in media framing, frame setting, journalism and media studies. 